Article

\title{
Does Internal Control Contribute to a Firm's Green Information Disclosure? Evidence from China
}

\author{
Rongbing Huang ${ }^{1, *}$ and Yubo Huang ${ }^{2}$ \\ 1 School of accounting, Zhejiang Gongshang University, Hangzhou 310018, China \\ 2 College of computer science, Sichuan University, Chengdu 610207, China; hyb.ah@outlook.com \\ * Correspondence: hrongb007@163.com
}

Received: 13 March 2020; Accepted: 13 April 2020; Published: 15 April 2020

\begin{abstract}
The literature shows that a firm's environmental information disclosure is affected by internal and external factors. However, it is unclear whether internal control positively impacts a firm's green information disclosure. We collected data from the period 2010-2016 from either environmental reports or the environmental section of social responsibility reports of A-share listed companies in the heaviest polluting industries of the Chinese capital market, 1603 companies in total, and established an evaluation index for measuring firm greenness. Our research indicates that the level of internal control was positively correlated to the firm's greenness level, and deficiencies in internal control were negatively correlated to the firm's greenness level, indicating that high-quality internal control improves company green information disclosure. Pertaining to property rights, the internal control of state-owned enterprises had a significant effect on improving the level of environmental information disclosure. Among five elements of internal control, the internal environment, information and communication elements had a significant positive impact on firm greenness. Compared with samples with uncorrected major deficiencies in internal control, rectified companies' environmental information disclosure was greener. These findings provide empirical evidence for a comprehensive understanding of the non-financial reporting goals of firm internal control, and will become a useful reference for firm green governance decision-making.
\end{abstract}

Keywords: internal control; environmental information disclosure; greenness level; firm social responsibility; greenwashing; China

\section{Introduction}

While economic activities have produced a large amount of social wealth, they have also seriously damaged the natural environment. With increased attention on environmental issues, the idea that firms should fulfill their environmental protection responsibilities while pursuing economic benefits has gradually gained support. Firms are required to regularly disclose information on pollution discharges, environmental compliance, and environmental management; and it is an important way for the government, the public, and environmental organizations to understand a firm's environmental performance. The environmental information disclosure system has even been called the "third wave" in environmental control policy [1].

Since 2000, China has officially incorporated information disclosure into its policy toolbox for pollution control. In 2006, the Shenzhen Stock Exchange issued the Guides for Social Responsibility of Listed Companies to encourage listed companies to voluntarily disclose environmental information. Similarly, in 2008, the Shanghai Stock Exchange issued the Guides for Environmental Information Disclosure of Listed Companies, which clarified the scope of environmental information disclosure and procedural requirements. In 2010, the Ministry of Environmental Protection issued a draft of the Guidelines for Environmental Information Disclosure of Listed Companies, requiring listed 
companies in polluting industries to regularly disclose environmental information and release annual environmental reports. Although the government has attached great importance to disclosure, and the general public has shown concern for it, research on Chinese listed companies has found that the implementation of the environmental information disclosure system has not been as satisfactory as desired. The phenomenon of "greenwashing," which entails reporting good news instead of bad news and reporting symbolic initiatives that have not been actually taken, is widespread [2]. Huang and Chen [3] found that the reason for the poor outcome of environmental information disclosure and emission reduction was "adverse selection" in the implementation of the system, that is, the selective disclosure by listed companies and overall poor quality of the environmental information disclosure. Thus, promoting a firm's green information disclosure has become a major issue for governments, markets, and firms.

As an important governance mechanism for firms, internal control has become one of the most important means for listed companies to strengthen self-discipline and improve management. In 1992, the internationally authoritative internal control standard-setting body, the COSO (Committee of Sponsoring Organizations of the Treadway Commission), pointed out in the Internal Control-Integrated Framework that internal control helps ensure the efficiency and effectiveness of business operations, the reliability of financial reporting, and compliance with relevant laws and regulations. In 2002, the United States Congress passed the Sarbanes-Oxley Act (SOX), which requires all listed companies in the United States to disclose an evaluation report in their annual report on the effectiveness of internal control on financial reporting. An audit opinion on the effectiveness of the internal control related to the financial reporting of the listed company is also required.

Moreover, in 2004, the COSO released the Enterprise Risk Management-Integrated Framework based on its 1992 report. The framework expanded its financial reporting objectives, emphasized that internal control should provide reasonable assurance for companies to prepare reliable reports, and included firm internal and external reports with both financial information and non-financial information such as environmental and social responsibility. In 2011, the COSO further revised the statement of goals in the internal control framework, extending it to a broader set of integrated reporting goals for finance, the environment, society, and governance.

In 2008, five Chinese ministries and commissions, including the Ministry of Finance, the China Securities Regulatory Commission, and the National Audit Office, issued the Basic Norms of Enterprise Internal Control, and subsequently, in 2010, jointly issued the Guides for the Application of Internal Control, the Guides for the Evaluation of Internal Control, and the Guides for Auditing of Internal Control. The aforementioned basic standards and supporting guidelines together constitute a Chinese firm's internal control standards system. That is, the system not only draws on and integrates the beneficial elements from the COSO report and the SOX Act, but also reflects the special characteristics of the Chinese capital market. Thus, it is known as the Chinese version of the COSO Report + SOX Act (hereafter referred to as CSOX). For example, unlike the SOX Act, which focuses on the internal control of financial reporting, CSOX extends to the operational and management level, requiring companies to disclose both major deficiencies in internal control over financial and non-financial reporting. Additionally, the external auditor must state major deficiencies in internal control over non-financial reporting discovered during the audit. In fact, many firm behaviors are related both to the internal control of financial reporting and to the firm's internal control as a whole. This system design provides a rare condition for analyzing whether the firm's internal control as an institutional norm has spillover effects on non-financial reports.

Based on the notion of CSOX, our research used data from the environmental report or the environmental section of the social responsibility report of listed companies in heavily polluting industries of the Chinese capital market to investigate whether a firm's internal control helps enhance the reliability of non-financial reports and standardize and improve the level of environmental information disclosure, thus promoting the firm's "green" social responsibility practices. 
This study used the greenness level in the disclosure of a firm's environmental information as the predicted variable and the level of internal control and internal control deficiencies as explanatory variables. The results indicate that after controlling for the influence of other factors, a high level of internal control improves a firm's green environmental information disclosure, and internal control deficiencies reduces such disclosure. The above findings show that internal control helps improve the reliability of firm non-financial reporting, and provides China-based empirical evidence for the goal of external reporting under the internal control system. Further testing based on the nature of property rights showed that the state-owned firms were proactive and demonstrative in terms of shouldering social responsibilities. The test based on the five components of internal control showed that a good internal environment and effective information and communication positively (and significantly) affected firm greenness. Results also indicate companies that had earlier made substantial rectifications of major internal control deficiencies had a higher level of greenness in the disclosure of environmental information.

The remainder of this paper is arranged as follows: Section 2 reviews the literature; Section 3 details the theoretical analysis and research question; Section 4 describes the research design; Section 5 details the empirical tests; Section 6 further discussion; and Section 7 provides the research conclusions.

\section{Literature Review}

Firm environmental information disclosure is affected both by internal and external factors. Researchers mainly study the impact of internal factors on environmental information disclosure from company characteristics, industry nature, and firm governance. External factors focus on the impact of public pressure on the level of environmental information disclosure.

\subsection{Company Characteristics}

The size of a firm company is found to be positively correlated to environmental information disclosure. The larger a company's assets, the more likely it is to increase the level of environmental information disclosure [4-6]. Better-performing companies also tend to disclose more environmental information $[7,8]$.

Furthermore, Meng et al. [9] investigated China's capital market and found that the relationship between firm performance and environmental information disclosure levels was complex, and the interactive impact of ownership and economic performance on environmental information disclosure level changed from the voluntary disclosure stage to the mandatory disclosure stage. In addition, $\mathrm{Lu}$ and Abeysekera [10] found that in China, social and environmental information disclosure had a significant positive correlation with company size, profitability, and industry classification. The research by Mohd Ghazali [11] on Malaysian listed companies found that due to the natural political connection with government, state-owned firms were more inclined to disclose social responsibility information than non-state-owned firms. Kuo et al. [12] found that the same was true in China, where state-owned firms have higher levels of environmental information disclosure than private firms. Zeng et al. [13] conducted analysis using data from listed Chinese manufacturing companies from 2006 to 2008, and found that state-owned firms had higher levels of environmental information disclosure. Cheng et al. [14] examine the influence of corporate political connections on corporate environmental information disclosure levels in China. They point out that although corporate political connections can influence companies to more actively disclose environmental information, it can also mask political rent-seeking in the guise of protecting the environment. In addition, the literature indicates that company characteristics such as financial leverage, capital requirements, and equity structure also impact environmental information disclosure [15-18].

\subsection{Industry Nature}

A study by Jose and Lee [19] found that environmentally sensitive industries, such as the power and oil industries, had more environmental information disclosures, whereas non-environmentlly 
sensitive industries, such as securities and finance, had fewer environmental information disclosures. García-Ayuso and Larrinaga [20] studied 112 industrial companies in the Spanish capital market and found that companies that disclosed environmental information were often in industries with higher potential environmental impacts. Brammer and Pavelin [21] selected 450 companies in the United Kingdom that voluntarily disclosed environmental information, and found that companies in polluting industries such as steel and coal had higher levels of environmental information disclosure. Clarkson et al. [22] used the Australian National Corporation's National Pollutant Inventory (NPI) emissions data, and the results showed that companies with a higher tendency to produce heavy pollution disclosed more environmental information. Studies by $[12,13]$ reached similar conclusions. In China, listed companies in environmentally sensitive industries place greater emphasis and disclose more information.

\subsection{Firm Governance}

Iatridis [16], Khan et al. [23] found that the proportion of independent directors, auditor reputation, the proportion of shares held by senior management, and the proportion of shares held by institutional investors were significantly positively correlated to the quality of environmental information disclosure. Peter and Romi [24] found that establishing environmental professional committees and increasing the number of board meetings improved the level of environmental information disclosure, whereas the increase in the size of the board reduced the transparency of environmental information. A study by Liao et al. [25] found that gender diversity on the board of directors was positively correlated to the propensity to disclose greenhouse gas information. Mahmood et al. [26] pointed out that a large board composed of female directors, and a firm's social responsibility committee contributed to better disclosure of sustainability information. Giannarakis et al. [27] use a sample of a total of 278 firms from the United States listed in the Standard and Poor's (S\&P) 500. Their results revealed that the age of the youngest director has a negative effect on environmental disclosure, while in contrast independent directors and the presence of lead independent directors strengthen the decision to develop environmental disclosures. Furthermore, Lagasio and Cucari [28] found that board independence, board size and female director status significantly improved environmental, social, and governance (ESG) voluntary disclosures; whereas board ownership and chief executive officer (CEO) duality did not. Pucheta-Martínez and López-Zamora [29] analyze the role performed by representatives of institutional investors in environmental reporting in Spain. Their findings show the engagement with the stakeholders of a particular type of director on boards regarding environmental disclosure. Lewis et al. [30] analyzed the response of CEOs' personal characteristics to the carbon emission disclosure project, and found that newly appointed CEOs and companies led by CEOs with a Master of Business Administration (MBA) were more likely to respond to the project, whereas lawyer-led companies were less likely to respond. Meng et al. [31] studied the relationship between executive turnover and environmental information disclosure based on data from the Chinese capital market, and found that involuntary replacement of executives was significantly negatively correlated to the adequacy of environmental information disclosure, whereas voluntary replacement of executives was not significantly correlated to the adequacy of environmental information disclosure.

\subsection{Public Pressure}

The level of environmental information disclosure is a function of the public pressure on the company [32]. Facing increasingly serious environmental problems, countries have formulated stricter environmental protection regulations and environmental access standards, which have challenged the legitimacy of firm environmental behaviors, and imposed institutional pressure on the disclosure of firm environmental information. Empirical research indicates that listed companies use environmental information disclosure to cope with institutional pressures in order to achieve legitimacy in firm maintenance, restoration, and continuous operation [5,33,34]. Meng et al. [9] analyzed the performance of companies in the two stages of voluntary disclosure and mandatory disclosure of environmental 
information against the Chinese background and pointed out that impression management theory could be used to explain firm performance during voluntary disclosure, and legitimacy theory could be used to explain mandatory firm performance during the mandatory disclosure. Yao and Liang [35] find that regulatory distance and political geography had negative effects on environmental information disclosure from Chinse companies, while political geography weakens regulatory distance's function. Li et al. [36] reveal that environmental legitimacy significantly negatively influences the likelihood of corporate carbon disclosure. They also show that green process innovation mediates the relationship, while green product innovation has no significant mediating effect. Similarly, D'Amico et al. [37] found that the introduction of ad hoc legislation as purely voluntary only affects the contents of quantitative environmental disclosures, which are unsuitable for a highly industrialized developed country. Hoang et al. [38] study firms' responses to two US Environmental Protection Agency (EPA) information-based interventions, and point out that firms are not unconditional greenwashers or environmental stewards. Rather, firms strategically invest resources to better pursue environmental stewardship while taking into account multiple signals from their key stakeholders, which includes the EPA. Barakat et al. [39] compared and evaluated the level of disclosure of social and environmental information in Palestine and Jordan. Although there were some differences in the number and content of disclosures, social and environmental information disclosure in both countries was positively related to legal systems and firm governance factors. Chelli [40] evaluates and compares the environmental reporting practices of a sample of French and Canadian companies through the lens of institutional legitimacy. The findings reveal that the French parliamentary regime is more successful than the Canadian stock exchange regulation in triggering environmental reporting. In addition, it was found that combined GRI and local regimes prompt environmental disclosures.

Environmental accidents can easily lead to public pressure. After environmental accidents, information disclosure becomes an even more important means for companies to alleviate external pressures and maintain social reputation [41]. Walden and Schwartz [42] investigate the changes in the levels of environmental disclosures subsequent to the 1989 Alaskan Exxon Valdez oil spill in four industries including the oil industry. They found that the environmental information disclosure level of 53 companies significantly improved within two years of the spill. Heflin and Wallace [43] analyzed the impact of BP's Gulf of Mexico oil spill accident, and found that among oil and gas companies drilling in US waters, environmental information disclosure, especially disaster preparedness plan disclosure, increased significantly within one year of the spill.

Social media plays an active role in environmental incidents through the top-down intervention mechanism, and the bottom-up reputation mechanism [44]. García-Ayuso and Larrinaga [20] pointed out that in Spain, two factors directly related to the amount of environmental information disclosure were the potential environmental impact of the industry and the degree of media coverage of companies in the industry. Based on an analysis of British companies, Brammer and Pavelin [21] found a significant positive correlation between media exposure and the improvement of firm environmental information disclosure quality. Similarly, Aerts and Cormier [45], Rupley et al. [46] showed that US and Canadian listed companies were sensitive to negative media environmental reports. Li et al. [47], based on studies of listed companies in Chinese industries with heavy pollution, found that company executives tended to rationalize excess pay by manipulating environmental information disclosure levels; and that media pressure weakened the self-serving tendency.

\subsection{Brief Comments}

Research in social and environmental accounting has witnessed its fair share of struggles within both the mainstream and critical accounting literature [48]. The environmental problems faced by China have not developed over a short period of time. Rapid economic growth, high resource consumption and high environment pollution are closely related to the assessment mechanism used by central government to review local officials. For a long time, the political progress of Chinese government officials at all levels has been presented by a form of promotion tournament [49]. This 
kind of performance concept can be expressed in the terms that the central government has demands on economic growth, but local officials need promotion. Therefore, the central government takes the economic growth as the assessment indicator for promotion and the system arrangement of "the central government supplies political promotion, and obtains economic growth; local officials supply economic growth and obtain political promotion" is formed. Due to promotion pressure and interest rent-seeking etc., local officials are strongly encouraged to pursue economic growth, and take a tacit or even conniving attitude to the practice that enterprise promotes local GDP growth through discharging pollutants. Environmental regulation is often "loosened" and "weakened". Local governments pay special attention to economic indicators such as GDP growth, but neglect environmental indicators such as unit GDP emissions, which has led to the "incomplete implementation" of some environmental legal instruments issued by the central government [50]. Research based on China indicates that external institutional pressures have a weaker explanatory power on environmental information disclosure $[10,13,51]$. Therefore, it is particularly important to examine the impact of internal factors on the level of environmental information disclosure of Chinese companies.

At present, there is a lack of research on the influencing factors of environmental information disclosure from the more detailed level of internal control. Such research would have strong academic value in showing how companies can improve the level of environmental information disclosure. The symbolic response and "greenwashing" behaviors of firms in environmental information disclosure have caused widespread concern [52-54]. From the perspective of green information disclosure in both words and action, we explored the impact of internal control on the level of firm environmental information disclosure to close a gap in the literature.

\section{Theoretical Analysis and Research Question}

Legitimacy is a key resource for the survival and development of an organization, and environmental performance has become an important aspect of the legitimacy of modern firms [54]. Environmental information disclosure enables organizations to maintain legitimacy without changing economic models [55]. Although firms disclose environmental information, their intention is most likely to meet the requirements of regulators and the demands of the public. The green market is a typical asymmetric information market: the public does not know whether the company issuing the information truly fulfills its environmental responsibility [56]. In some firms, green management behaviors have tended to be limited to greenwashing behaviors [57,58]. Greenwashing has become a decoupling strategy for them to obtain legitimacy [59]. In the process of information disclosure, such firms often employ word games in specious information disclosures and use vague, ambiguous language and symbolic expressions to overstate their environmental performance. Thus, their legitimacy is derived from a false narrative rather than the truth [60]. Even if some environmental information is disclosed, the authenticity and quality of the information are generally low [61].

Environmental problems typically have cumulative, long-term characteristics. To solve environmental problems faced by transitional economies, such as China, we need to improve the transparency and reliability of environmental information disclosure and encourage firms to implement green social responsibility practices.

Internal controls may impact firm green information disclosure in several ways. First, the establishment of internal control systems has become an important means of improving firm governance in countries around the world. The integration of internal control and firm governance can increase the group's decision-making ability, encourage and supervise agents, suppress agency problems, and improve firm governance while strengthening internal control. Johnstone et al. [62] examined the relationship between the disclosure of internal control deficiencies and the improvement of firm governance. They found that, compared to companies with unqualified opinions in their reporting, companies identified as having major internal control deficiencies had a higher turnover rate in their boards, audit committees, and senior management after an audit report. Furthermore, compared with companies that had not corrected major deficiencies, those that had corrected major deficiencies 
made significant improvement in the structure of the board of directors, audit committees, and senior management. The literature confirms that good firm governance, diversity of the board of directors, and improvement in the educational qualifications of senior management can effectively restrain a company's environmental pollution, improve its environmental information disclosure level, and promote the true fulfillment of the company's environmental commitments $[23,25,28,30]$. Therefore, high-quality internal control through improvement of firm governance can help reduce the self-interested motivation of managers and controlling shareholders, maximize the protection of the rights and interests of various stakeholders, and provide reasonable assurance of reliable firm environmental reporting.

Second, the "triple bottom line" reflects a company's commitment to environmental protection, social equity, and economic development [63]. The aim is to infuse the concept of sustainable development with company's values and business practices. Environmental, social, and financial performance can be managed as a whole. The triple bottom line requires companies to attach the same importance to environmental and social goals as it does to financial goals, and to sacrifice the company's short-term to medium-term financial benefits for this purpose. At present, many companies' sustainable development reports, social responsibility reports, and environmental reports are prepared using the triple bottom line or similar principles and disclose environmental financial information and environmental performance information in accordance with a common framework. A green company should be consistent in its environmental commitments and environmental performance and ensure that what has been said in the environmental information disclosure matches what has been done, which obviously requires that all matters of the company must follow the principles of fairness and ethics. Companies with high internal control quality have a more honest firm culture, a stronger sense of teamwork, and more responsible and high-quality employees [64], which can undoubtedly provide effective assurance for improving firm social responsibility and environmental information transparency and promoting the fulfillment of environmental protection responsibilities.

Third, compared with green firms, the problem of greenwashing is an information asymmetry problem. In order to establish a good image, companies selectively disclose positive environmental information and conceal negative environmental information; they disclose more qualitative and non-monetized "soft information," and less quantitative and monetized "hard information" [45,65]. According to the Risk Management-Integrated Framework released by COSO, one of the core objectives of internal control is the reporting reliability. Existing studies have found that companies with higher internal control quality have less information asymmetry [66]. In the process of environmental information reporting internally and externally, effective communication occurs in the upward, parallel, and downward flow of information in the firm, and the information is conveyed to personnel related to environmental protection so that they can perform duties such as verification, supervision and inspection. Thanks to the sufficient information transmission mechanism, efficient communication channels, and a rigorous monitoring system in the high-quality internal control, even if there is a greenwashing motive in the company, the motive will fail because the company is often "exposed to the sun" and lacks favorable opportunities for action. For non-financial information, such as environmental reports, effective internal control can also reduce information asymmetry, thereby reducing moral hazard and the adverse selection behavior of firms in environmental information disclosure.

Fourth, uncertainties related to environmental issues increase the operating risks of listed companies and may have an adverse and negative impact on the company's finance, operation, and reputation. Regular disclosure of environmental information has become a way for companies to respond to risks and maintain legitimacy. In the Chinese version of the Basic Norms of Enterprise Internal Control (CSOX), companies are clearly required to show concern for employees' health, safety, and environmental protection in risk assessment, indicating that internal control, as a system for regulating firm behavior, has been expanded to environmental protection [67]. The Guides for the Application of Internal Control No. 4-Social Responsibility, issued in 2010, clearly state that environmental protection and resource conservation are social responsibilities and obligations that firms 
should perform. They are required to establish a monitoring system, regularly carry out supervision and inspection, and correct problems in a timely manner. Emergency and major environmental pollution incidents should also be reported and dealt with in a timely way. As the internal control standards and their supporting guidelines are gradually implemented in Chinese listed companies, internal control has become an important governance mechanism that encourages firms to actively take on social responsibilities. It can have a positive influence on improving the level of firm environmental information disclosure and the actual performance of entrusted environmental responsibilities.

Based on the above analysis, we developed the following proposition: the level of internal control has a positive impact on a firm's green information disclosure.

\section{Research Design}

\subsection{Sample Selection}

This study took heavily polluting, A-share listed companies from the Shanghai Stock Exchange and Shenzhen Stock Exchange as research objects. Specifically, it included 19 sub-sectors from the China Securities Regulatory Commission's Guidelines for the Classification of Listed Companies by Industry: (1) coal mining and cleaning, (2) oil and gas mining, (3) ferrous metal ore mining and dressing, (4) non-ferrous metal ore mining and dressing, (5) food manufacturing, (6) wine, beverage, and refined tea manufacturing, (7) textiles, (8) leather, fur, feather, and its products, and shoe manufacturing, (9) paper and paper products, (10) petroleum processing, coking, and nuclear fuel processing, (11) chemical raw materials and chemical products manufacturing, (12) pharmaceutical manufacturing, (13) chemical fiber manufacturing, (14) rubber and plastic products, (15) non-metallic mineral products, (16) ferrous metal smelting and rolling processing, (17) non-ferrous metal smelting and rolling processing, (18) metal products, (19) electric power, heating power production, and supply.

The above industries, according to the National Environmental Protection Agency's Guidelines for Environmental Information Disclosure of Listed Companies, should regularly and independently disclose environmental information, and thus these industries are representative. Furthermore, selecting the above industries for analysis can help control the impact of external pressures to better examine the impact of internal control on the level of environmental information disclosure.

From 2010 to 2016, a total of 318 A-share listed companies in the heavily polluting industries disclosed environmental information via independent reports, totaling 1681 firm-year observations. The sample selection process and annual sample size are shown in Table 1.

Table 1. Sample selection and sample size each year.

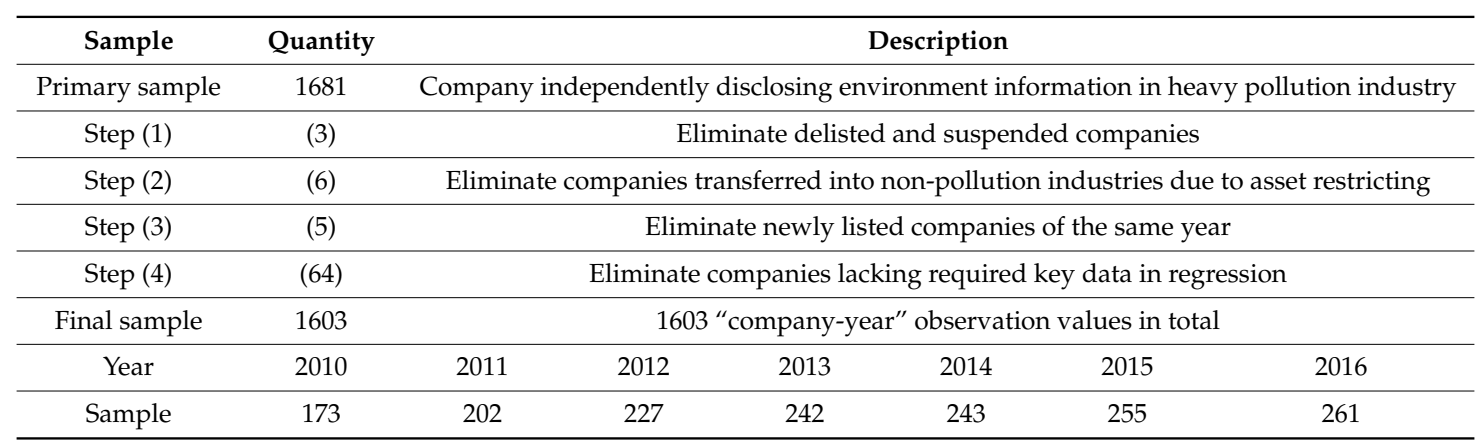

This study used independent mixed-section data modeling. By studying the firm environmental reports and the environmental section in either the social responsibility or sustainable development reports, we hand collected and calculated data for environmental information disclosure. Financial data and company characteristics were derived from the Database of China Stock Market Accounting Research (CSMAR). The internal control data came from the Database of Shenzhen Dibo's Internal 
Control and Risk Management (DIB). To avoid the influence of extreme values, winsorization was performed on top and bottom $1 \%$ samples of the continuous control variables in the regression model.

\subsection{Definition of Variables}

Based on the research question proposed earlier, we constructed the following regression model:

$$
\text { Green }=\alpha+\beta_{1} \text { Icr }+\sum \beta_{i} \text { Controls }+ \text { Industry }+ \text { Year }+\varepsilon
$$

where Green is the explained variable indicating the greenness level of a firm's environmental information disclosure, and Icr is a key explanatory variable used to measure the level of internal control.

The detailed descriptions of the main variables are explained as follows:

\subsubsection{Level of Greenness (Green)}

Green is the opposite concept of greenwashing, which can be converted by the degree of greenwashing $(G w l)$.

$$
\text { Green }=100-G w l
$$

The environmental performance of a greenwashing company is much lower than its environmental commitments. After eliminating threats to legitimacy or winning a social reputation, companies often put aside high-profile environmental commitments [59,68]. Impression management theory explains the opportunistic behavior of companies in their external reporting and disclosure of information [69]. In order to establish a green impression, the company may either implement protective impression management, that is reporting good news but not bad news to cover up inactions in environmental protection, or adopt acquired impression management, that is reporting more environmental measures than are utilized, and using symbolic expressions instead of substantive actions for greenwashing [2].

Referring to practice of relevant literatures $[45,53,54,56]$, the level of greenness is measured by three steps.

First, based on the theory of impression management, we defined the greenwashing strategy of firms as selective disclosure and expressive manipulation. According to the requirements of relevant laws, announcements, standards and guidelines, we summarized the items that should have been disclosed in the firm environmental report (shown in Table 2). In fact, companies may have commitments or performance in some areas, but no commitments or performance in others. We used the ratio of firm undisclosed items to all items that should have been disclosed to measure the degree of selective disclosure:

Selective disclosure $(\mathrm{Gwls})=100 \times(1-$ number of items disclosed/number of items should to be disclosed $)$

In an environmental report, one must judge whether a company's environmental performance is a substantial action or a symbolic expression. According to the literature [54,65], if a company discloses more verifiable and difficult-to-imitate information through factual statements, case descriptions, and quantitative descriptions, its environmental information disclosure is highly reliable and is considered a substantive action. One such example is: "The company implemented the limestone/gypsum wet flue gas desulfurization process transformation for the desulfurization equipment of the branch power plant. A total of 15.6417 million yuan was invested in the reporting period to achieve a reduction of 7.33 tons of sulfur dioxide per year, nitrogen oxides reduction of 9.02 tons/year, and the by-product calcium sulfate dihydrate brought economic benefits of 1.1605 million yuan/year ... " Conversely, if a company's environmental report is mainly a summary statement, a qualitative disclosure, or a simple copy of the previous year's statement that appears to be difficult to verify and easy to imitate, its environmental information disclosure is less reliable, and is a symbolic expression. An example is: "The company has renovated some of its waste gas treatment facilities and achieved good environmental, economic, and social benefits during the reporting period." 
Table 2. Measurement indicator system for greenwashing.

\begin{tabular}{|c|c|c|c|c|c|}
\hline \multirow{2}{*}{ Sequence } & & \multirow{2}{*}{ Item } & \multirow{2}{*}{$\begin{array}{c}\text { Items that Should } \\
\text { Have Been Disclosed }\end{array}$} & \multicolumn{2}{|c|}{ Disclosed Items } \\
\hline & & & & Symbolic & Substantive \\
\hline 1 & \multirow{4}{*}{$\begin{array}{l}\text { Governance and } \\
\text { structure }\end{array}$} & Environmental policy and strategy & & & \\
\hline 2 & & $\begin{array}{l}\text { Environmental protection goals and } \\
\text { realization }\end{array}$ & & & \\
\hline 3 & & $\begin{array}{c}\text { Environmental regulations and } \\
\text { enforcement }\end{array}$ & & & \\
\hline 4 & & $\begin{array}{l}\text { Environmental management agency } \\
\text { and operation }\end{array}$ & & & \\
\hline 5 & \multirow{5}{*}{ Process and control } & $\begin{array}{l}\text { Environmental certification system } \\
\text { and implementation }\end{array}$ & & & \\
\hline 6 & & $\begin{array}{l}\text { Environmental honors and } \\
\text { recognition }\end{array}$ & & & \\
\hline 7 & & $\begin{array}{l}\text { Environmental protection } \\
\text { investment and comprehensive } \\
\text { improvement plan }\end{array}$ & & & \\
\hline 8 & & $\begin{array}{l}\text { Environmental education training } \\
\text { and public welfare activities }\end{array}$ & & & \\
\hline 9 & & $\begin{array}{l}\text { Environmental technology research } \\
\text { and development }(\mathrm{R} \& \mathrm{D}) \text { and } \\
\text { process innovation }\end{array}$ & & & \\
\hline 10 & \multirow{7}{*}{ Input and output } & $\begin{array}{c}\text { Energy consumption and reduction } \\
\text { measures }\end{array}$ & & & \\
\hline 11 & & $\begin{array}{c}\text { Water consumption and reduction } \\
\text { measures }\end{array}$ & & & \\
\hline 12 & & $\begin{array}{l}\text { Greenhouse gas emissions and } \\
\text { reduction measures }\end{array}$ & & & \\
\hline 13 & & $\begin{array}{l}\text { Exhaust emissions and reduction } \\
\text { measures }\end{array}$ & & & \\
\hline 14 & & $\begin{array}{l}\text { Wastewater generation and } \\
\text { reduction measures }\end{array}$ & & & \\
\hline 15 & & $\begin{array}{l}\text { Amount of solid waste generated } \\
\text { and treatment measures }\end{array}$ & & & \\
\hline 16 & & $\begin{array}{l}\text { Other emission reduction measures } \\
\text { such as noise, paperless and } \\
\text { logistics }\end{array}$ & & & \\
\hline 17 & \multirow{4}{*}{$\begin{array}{l}\text { Law and regulation } \\
\text { compliance }\end{array}$} & $\begin{array}{l}\text { Statement of compliance with } \\
\text { environmental laws and regulations }\end{array}$ & & & \\
\hline 18 & & $\begin{array}{l}\text { Risk assessment from } \\
\text { environmental policies }\end{array}$ & & & \\
\hline 19 & & $\begin{array}{l}\text { Statement of industry characteristics } \\
\text { on environmental impact }\end{array}$ & & & \\
\hline 20 & & $\begin{array}{l}\text { Statement of whether a major } \\
\text { environmental pollution accident } \\
\text { has occurred }\end{array}$ & & & \\
\hline \multicolumn{4}{|c|}{ Total } & & \\
\hline
\end{tabular}

We used the ratio of symbolically disclosed items to items that have been disclosed in firm disclosure to measure the degree of expressive manipulation:

Expressive manipulation $($ Gwle $)=100 \times($ number of symbolically disclosed items $/$ number of disclosed items)

Second, we constructed an indicator system to measure greenwashing with 20 questions from four categories: governance and structure, process and control, input and output, and law and regulation compliance, as shown in Table 2. The content analysis method was used to score items related to environmental information disclosure: "Yes" was assigned a value of 1 ; and "No" was assigned a value of 0 . Consistent with the steps of the content analysis method, in the scoring process, each sample was scored separately by two people. The official scoring was only started when the consistency between 
the two raters reached higher than $90 \%$ in the trial evaluation stage. Discrepancy between the two raters was resolved through a third rater.

The scores of selective disclosure and expressive manipulation were calculated, which respectively represented the assessment of the quantity and quality of environmental information disclosure, and the geometric mean was used to calculate the level of greenwashing $(\mathrm{Gwl})$ of the firm.

$$
G w l=\sqrt{G w l s \times G w l e}
$$

Finally, using Equation (2), we calculated the level of greenness (Green) of each company's environmental information disclosure. This indicator adopted a percentage system. The higher the score, the higher the level of greenness:

\subsubsection{Internal Control Level (Icr)}

Icr is directly measured using the five-component-based internal control index developed by Shenzhen Dibo. Shenzhen DIB is a professional and authoritative internal control information data supplier in China. It developed internal control indexes, combined with the 2013 Internal Control-Integration Framework issued by COSO and its supporting guidelines, and relevant standards and systems issued by the Ministry of Finance and China Securities Regulatory Commission, which reflect the internal control level of listed companies in China from the perspective of information disclosure. Chinese scholars utilize the database to publish academic papers in international journals. This index consists of five first-level indicators (internal environment, risk assessment, control activities, information and communication, and internal supervision), 31 secondary indicators, and 87 evaluation indicators [70].

In order to ensure the robustness of the results, the study used internal control deficiency (Icminus) as a proxy variable of the level of internal control. The paper starts from practice inspection standards, based on internal control results, and focuses on internal control objective realization degree to alternatively measure internal control quality. Internal control objectives in CSOX include: to reasonably guarantee enterprise operation management legitimacy and compliance, asset safety, authenticity and integrity of financial statements and related information, improvement of operation efficiency and effect and promotion of the enterprise to realize the development strategy. Referring to the studies by Fang and Jin [71], Liu and Liu [72] and Chen and Xu [73], we chose circumstances that obviously showing unrealized internal control objectives to reflect internal control defects, and where there are internal control defects they are used as contrary indicators to measure internal control quality. Internal control deficiency (Icminus) was assigned a value of 1 if any of the following conditions existed: (1) a non-standard audit opinion was issued in the financial report, (2) a restatement was issued for the financial statements, or (3) the company was penalized by the China Securities Regulatory Commission, the Stock Exchange or the Ministry of Finance for violations; and given these situations, a description of major deficiencies was included in the company's internal control in the relevant year. Otherwise, Icminus was assigned a value of 0 .

\subsubsection{Control Variable (Controls)}

Based on the environmental information disclosure literature, Equation (1) incorporates the following variables: regional economic development level ( $\operatorname{npg} d p$ ), company size (Lnasset), profitability (Roa), financial leverage (Lev), growth (Growth), loss (Loss), whether the chairman of the director served as the general manager (Ndual), independent director ratio (Idr), and individual stock return (Rate) to control the impact of the company-specific characteristics. In addition, we also added Industry and Year to Equation (1). Specific definitions of the variables are shown in Table 3. 
Table 3. List of variable definitions.

\begin{tabular}{|c|c|c|c|}
\hline Variable Type & Variable Symbol & Variable Name & Calculation Method \\
\hline $\begin{array}{l}\text { Explained } \\
\text { variable }\end{array}$ & Green & Greenness level & See explanation in the paper. \\
\hline \multirow[b]{2}{*}{$\begin{array}{l}\text { Explanatory } \\
\text { variables }\end{array}$} & Icr & Level of internal control & $\begin{array}{l}\text { Adopted the internal control index developed by Shenzhen } \\
\text { Dibo }\end{array}$ \\
\hline & Icminus & $\begin{array}{l}\text { Deficiencies in internal } \\
\text { control }\end{array}$ & $\begin{array}{c}\text { A value of } 1 \text { was assigned if one of the following conditions } \\
\text { existed: (1) a non-standard audit opinion was issued in the } \\
\text { financial report, (2) a restatement was issued for the financial } \\
\text { statements, or (3) the company was penalized for violations } \\
\text { by the China Securities Regulatory Commission, the Stock } \\
\text { Exchange, or the Ministry of Finance; otherwise, a value of } 0 \\
\text { was assigned. }\end{array}$ \\
\hline \multirow{11}{*}{$\begin{array}{c}\text { Control } \\
\text { variables }\end{array}$} & Lnpgdp & $\begin{array}{l}\text { Level of economic } \\
\text { development }\end{array}$ & $\begin{array}{l}\text { Natural logarithm of per capita GDP }(10,000 \text { yuan) of the } \\
\text { company's location }\end{array}$ \\
\hline & Lnasset & Company size & Natural logarithm of total assets at the end of the period \\
\hline & Roa & Profitability & Net profit/average balance of total assets \\
\hline & Lev & Financial leverage & $\begin{array}{l}\text { Total liabilities at the end of the period/total assets at the end } \\
\text { of the period }\end{array}$ \\
\hline & Growth & Growth & $\begin{array}{l}\text { (Revenue from the main business of the current } \\
\text { period-Income from the main business of the previous } \\
\text { period)/Revenue of the main business of the previous period }\end{array}$ \\
\hline & Loss & Loss or not & 1 if the company had a current loss, otherwise 0 \\
\hline & Ndual & Dual role & $\begin{array}{l}1 \text { when chairperson of director and general manager were the } \\
\text { same person; otherwise } 0\end{array}$ \\
\hline & $I d r$ & $\begin{array}{l}\text { Proportion of } \\
\text { independent directors }\end{array}$ & Number of independent directors/all board directors \\
\hline & Rate & Individual stock return & $\begin{array}{l}\text { Annual stock returns taking into account the cash dividend } \\
\text { reinvestment }\end{array}$ \\
\hline & Industry & Industry variable & $\begin{array}{c}\text { The value = } 1 \text { when the sample was for a specific industry; } \\
\text { otherwise } 0 .\end{array}$ \\
\hline & Year & Year variable & $\begin{array}{c}\text { The value }=1 \text { when the sample was for a specific year; } \\
\text { otherwise } 0 .\end{array}$ \\
\hline
\end{tabular}

\section{Empirical Testing}

\subsection{Descriptive Statistics}

The descriptive statistics are shown in Table 4. The average greenness level (Green) was 45.81, the median was 46.49 , the minimum value was 2.53 , and the maximum value was 95 , showing that the greenness level of the analyzed companies was not high and varied greatly from company to company.

Table 4. Descriptive statistics.

\begin{tabular}{ccccccc}
\hline Variable & Count & Mean & Sd & P50 & Min & Max \\
\hline Green & 1603 & 45.808 & 20.608 & 46.486 & 2.532 & 95.000 \\
\hline Icr & 1603 & 34.436 & 8.300 & 35.040 & 7.000 & 59.000 \\
\hline Icminus & 1603 & 0.265 & 0.441 & 0.000 & 0.000 & 1.000 \\
\hline Lnpgdp & 1603 & 10.829 & 0.470 & 10.853 & 9.482 & 11.680 \\
\hline Lnasset & 1603 & 23.012 & 1.465 & 22.812 & 19.198 & 28.509 \\
\hline Roa & 1603 & 0.043 & 0.062 & 0.034 & -0.178 & 0.249 \\
\hline Lev & 1603 & 0.485 & 0.208 & 0.492 & 0.042 & 1.003 \\
\hline Growth & 1603 & 0.131 & 0.332 & 0.090 & -0.518 & 2.745 \\
\hline Loss & 1603 & 0.100 & 0.301 & 0.000 & 0.000 & 1.000 \\
\hline Ndual & 1603 & 0.138 & 0.345 & 0.000 & 0.000 & 1.000 \\
\hline Idr & 1603 & 0.368 & 0.054 & 0.333 & 0.182 & 0.667 \\
\hline Rate & 1603 & 0.091 & 0.401 & 0.007 & -0.537 & 1.741 \\
\hline
\end{tabular}


The average value of internal control (Icr) was 34.44, the median was 35.04, the standard deviation was 8.3. The sample identification was good, which provided an opportunity to study the effect of internal control on firm greenness. The mean value of internal control deficiencies (Icminus) was 0.265, which meant that $26.5 \%$ of the samples had major internal control deficiencies.

The grouping of descriptive statistical results according to the level of internal control and whether there were major deficiencies in internal control are shown in Table 5. Whether using a mean test or a median test, the firm greenness level of the sample group with a high level of internal control was significantly higher than that of the sample group with a low level of internal control; the firm greenness level of the sample group without major deficiencies in internal control was significantly higher than that of the sample group with major deficiencies in internal control. The inter-group difference test provided supporting evidence for the stated proposition.

Table 5. Grouping descriptive statistics.

\begin{tabular}{|c|c|c|c|c|c|c|}
\hline \multirow{8}{*}{$\begin{array}{c}\text { Analytical } \\
\text { variable } \\
\text { Green }\end{array}$} & \multicolumn{6}{|c|}{ Grouping Variable Icr } \\
\hline & \multicolumn{2}{|c|}{$\begin{array}{l}\text { Sample group with } \\
\text { high level }\end{array}$} & \multicolumn{2}{|c|}{$\begin{array}{l}\text { Sample group with } \\
\text { low level }\end{array}$} & \multicolumn{2}{|c|}{ Difference test } \\
\hline & Mean & Median & Mean & Median & Mean test & Median test \\
\hline & 47.075 & 48.359 & 44.700 & 45.228 & $2.320 * *$ & $2.267 * *$ \\
\hline & \multicolumn{6}{|c|}{ Grouping Variable Icminus } \\
\hline & \multicolumn{2}{|c|}{$\begin{array}{l}\text { Sample group without major } \\
\text { deficiencies }\end{array}$} & \multicolumn{2}{|c|}{$\begin{array}{c}\text { Sample group with } \\
\text { major deficiencies }\end{array}$} & \multicolumn{2}{|c|}{ Difference test } \\
\hline & Mean & Median & Mean & Median & Mean test & Median test \\
\hline & 47.079 & 47.219 & 42.387 & 42.791 & $4.067^{* * *}$ & $3.935^{* * *}$ \\
\hline
\end{tabular}

\subsection{Analysis of Empirical Results}

Table 6 reports the results of Equation (1). The first column (1) used the internal control indicator (Icr) and OLS method. After controlling for the characteristics of firm operations and firm governance, it was significantly positive $(p<0.05)$, indicating that the higher the firm internal control, the higher the greenness of environmental information disclosure, and the more internal control contributed to the actual fulfillment of firm environmental responsibility, thus supporting our stated proposition. A quantile regression method was used for testing the grouping of high and low levels of firm greenness, and the results, shown in columns 2 and 3, indicate that after controlling for the characteristics of the company, the Icr coefficients for the $25 \%$ low quantile and the $75 \%$ high quantile were significantly positive $(p<0.01)$, which was consistent with the OLS regression results.

Columns 4-6 of Table 6 report regression results using the internal control deficiency Icminus. In every regression, the coefficient of the key explanatory variable Icminus was significantly negative $(p<0.01)$, meaning that a company with major internal control deficiencies had a significantly lower greenness level of environmental information disclosure. This provided more supporting evidence for the paper's stated proposition. 
Table 6. Empirical results.

\begin{tabular}{|c|c|c|c|c|c|c|}
\hline \multirow{2}{*}{ Green } & OLS & Q25 & Q75 & OLS & Q25 & Q75 \\
\hline & (1) & (2) & (3) & (4) & (5) & (6) \\
\hline Icr & $\begin{array}{l}0.1402 * * \\
(2.1775)\end{array}$ & $\begin{array}{l}0.0739^{* * *} \\
(18.5169)\end{array}$ & $\begin{array}{c}0.0945^{* * *} \\
(9.3876)\end{array}$ & & & \\
\hline Icminus & & & & $\begin{array}{c}-3.6724^{* * *} \\
(-3.3027)\end{array}$ & $\begin{array}{l}-5.1034^{* * *} \\
(-11.9500)\end{array}$ & $\begin{array}{l}-2.3904^{* * *} \\
(-12.0774)\end{array}$ \\
\hline$L n p g d p$ & $\begin{array}{c}1.4169 \\
(1.2500)\end{array}$ & $\begin{array}{l}2.6432 * * * \\
(21.2346)\end{array}$ & $\begin{array}{c}0.6933^{* * *} \\
(6.2435)\end{array}$ & $\begin{array}{c}1.2158 \\
(1.0720)\end{array}$ & $\begin{array}{c}1.0022^{* * *} \\
(8.6090)\end{array}$ & $\begin{array}{c}0.5709 * * * \\
(2.8390)\end{array}$ \\
\hline Lnasset & $\begin{array}{l}5.4957 * * * \\
(12.4569)\end{array}$ & $\begin{array}{l}5.6707^{* * *} \\
(198.4711)\end{array}$ & $\begin{array}{l}4.3357^{* * *} \\
(35.1277)\end{array}$ & $\begin{array}{l}5.3839 * * * \\
(12.0841)\end{array}$ & $\begin{array}{l}5.8049 * * * \\
(59.6940)\end{array}$ & $\begin{array}{l}4.0756^{* * *} \\
(136.3982)\end{array}$ \\
\hline Roa & $\begin{array}{l}10.6986 \\
(0.8724)\end{array}$ & $\begin{array}{c}26.1776^{* * *} \\
(49.3031)\end{array}$ & $\begin{array}{l}5.3069 * * \\
(2.1802)\end{array}$ & $\begin{array}{l}10.3528 \\
(0.8399)\end{array}$ & $\begin{array}{c}23.5370 * * * \\
(15.3547)\end{array}$ & $\begin{array}{c}14.1539 * * * \\
(6.6983)\end{array}$ \\
\hline Lev & $\begin{array}{c}0.2088 \\
(0.0607)\end{array}$ & $\begin{array}{l}4.1915^{* * *} \\
(25.4068)\end{array}$ & $\begin{array}{c}0.4094 \\
(0.5105)\end{array}$ & $\begin{array}{c}1.1018 \\
(0.3190)\end{array}$ & $\begin{array}{c}4.0478^{* * *} \\
(5.4735)\end{array}$ & $\begin{array}{c}2.1183^{* * *} \\
(7.4788)\end{array}$ \\
\hline Growth & $\begin{array}{l}-3.6628 * * \\
(-2.1883)\end{array}$ & $\begin{array}{l}-4.9343^{* * *} \\
(-40.5909)\end{array}$ & $\begin{array}{c}0.3867 \\
(1.5145)\end{array}$ & $\begin{array}{l}-3.8066^{* *} \\
(-2.2733)\end{array}$ & $\begin{array}{l}-5.3135^{* * *} \\
(-15.7503)\end{array}$ & $\begin{array}{c}-0.8228 * * * \\
(-6.5939)\end{array}$ \\
\hline Loss & $\begin{array}{l}-4.0617 * * \\
(-2.2373)\end{array}$ & $\begin{array}{l}-2.1564 * * * \\
(-18.8084)\end{array}$ & $\begin{array}{l}-5.1337^{* * *} \\
(-21.4676)\end{array}$ & $\begin{array}{l}-4.0364^{* *} \\
(-2.2453)\end{array}$ & $\begin{array}{l}-4.7287^{* * *} \\
(-19.0314)\end{array}$ & $\begin{array}{l}-4.1563^{* * *} \\
(-10.6619)\end{array}$ \\
\hline Ndual & $\begin{array}{c}-3.7575 * * * \\
(-2.7587)\end{array}$ & $\begin{array}{l}-2.4046^{* * *} \\
(-38.7853)\end{array}$ & $\begin{array}{l}-5.2424^{* * *} \\
(-19.4099)\end{array}$ & $\begin{array}{c}-3.6279 * * * \\
(-2.6704)\end{array}$ & $\begin{array}{c}-1.6378 \text { *** } \\
(-3.6376)\end{array}$ & $\begin{array}{l}-4.3969^{* * *} \\
(-12.1221)\end{array}$ \\
\hline$I d r$ & $\begin{array}{c}0.1056 \\
(0.0126)\end{array}$ & $\begin{array}{c}10.4643^{* * *} \\
(35.8557)\end{array}$ & $\begin{array}{c}-8.0839 * * * \\
(-6.3517)\end{array}$ & $\begin{array}{c}0.4623 \\
(0.0564)\end{array}$ & $\begin{array}{c}11.6379 * * * \\
(4.4924)\end{array}$ & $\begin{array}{c}-14.8611^{* * *} \\
(-16.2670)\end{array}$ \\
\hline Rate & $\begin{array}{c}-0.5379 \\
(-0.3863)\end{array}$ & $\begin{array}{c}-0.8960 * * * \\
(-7.5892)\end{array}$ & $\begin{array}{l}-3.1659 * * * \\
(-11.1398)\end{array}$ & $\begin{array}{c}-0.7212 \\
(-0.5187)\end{array}$ & $\begin{array}{c}-0.9567 * * * \\
(-2.6031)\end{array}$ & $\begin{array}{c}-1.9810^{* * *} \\
(-7.7461)\end{array}$ \\
\hline _Cons & $\begin{array}{c}-87.2054^{* * *} \\
(-6.2895)\end{array}$ & & & $\begin{array}{c}-78.5680 * * * \\
(-5.6099)\end{array}$ & & \\
\hline Ind & Control & Control & Control & Control & Control & Control \\
\hline Year & Control & Control & Control & Control & Control & Control \\
\hline $\mathrm{N}$ & 1603 & 1603 & 1603 & 1603 & 1603 & 1603 \\
\hline Adj. $\mathrm{R}^{2}$ & 0.2022 & & & 0.2057 & & \\
\hline
\end{tabular}

\subsection{Testing for Robustness}

The following robustness test was performed and the results indicated in Table 7.

1. The measurement of the firm greenness level (Green) and internal control level (Icr) both depended on the company's information disclosure. In reality, there may be missing variables that affect both the level of firm environmental information disclosure and the level of internal control information disclosure, resulting in the correlation between the compound disturbance and the explanatory variables in the OLS regression and creating endogeneity. This study used the two-stage regression method of instrumental variables to correct for endogeneity. The Shenzhen and Shanghai Stock Exchanges of China have different requirements for the disclosure of internal control information, which may affect the disclosure of firm internal control but should not affect the level of firm environmental information disclosure. Therefore, we chose the listing place as an instrumental variable. In addition, we selected the industry's internal control level for the previous year as an instrumental variable. The corresponding regression results are shown in column 1 in Table 7. The Chi-square value of the Kleibergen-Paap rk M statistic was about 4.57 , and the unrecognizable null hypothesis was rejected. The Chi-square value of the Hansen J 
statistic was approximately 0.05 , and the $p$-value was 0.8054 . The null hypothesis was accepted, indicating that the instrumental variable is exogenous and not related to the disturbance term. As indicated in Table 7, the coefficient of Icr was 4.1692 , which was significantly positive $(p<0.1)$, indicating even if we consider endogeneity, the effect of internal control on firm greenness is still significantly positive.

Table 7. Robustness test.

\begin{tabular}{|c|c|c|c|c|c|c|c|c|}
\hline \multirow{2}{*}{ Green } & \multirow{2}{*}{$\begin{array}{c}2 S L S \\
(1)\end{array}$} & \multirow{2}{*}{$\begin{array}{c}\text { Ologit } \\
(2)\end{array}$} & \multicolumn{2}{|c|}{ Deleted Variable } & \multicolumn{2}{|c|}{ Added Control Variable } & \multicolumn{2}{|c|}{ Bootstrap } \\
\hline & & & (3) & (4) & (5) & (6) & (7) & (8) \\
\hline Icr & $\begin{array}{l}4.1692 * \\
(1.9090)\end{array}$ & $\begin{array}{c}0.0378 * * \\
(2.0337)\end{array}$ & $\begin{array}{c}0.1432 * * \\
(2.2441)\end{array}$ & & $\begin{array}{l}0.1278^{* *} \\
(2.0012)\end{array}$ & & $\begin{array}{c}0.1402 * * \\
(2.1686)\end{array}$ & \\
\hline Icminus & & & & $\begin{array}{c}-3.7357^{* * *} \\
(-3.3616)\end{array}$ & & & & $\begin{array}{c}-3.6724^{* * *} \\
(-3.5127)\end{array}$ \\
\hline $\operatorname{Lnpgdp}$ & $\begin{array}{c}-1.3948 \\
(-0.5454)\end{array}$ & $\begin{array}{c}0.1647 \\
(1.4972)\end{array}$ & $\begin{array}{c}1.2423 \\
(1.0974)\end{array}$ & $\begin{array}{c}1.0398 \\
(0.9178)\end{array}$ & $\begin{array}{c}0.7954 \\
(0.5349)\end{array}$ & $\begin{array}{c}0.8012 \\
(0.5388)\end{array}$ & $\begin{array}{c}1.4169 \\
(1.2444)\end{array}$ & $\begin{array}{c}1.2158 \\
(1.0654)\end{array}$ \\
\hline Lnasset & $\begin{array}{c}5.1133 * * * \\
(6.0949)\end{array}$ & $\begin{array}{l}0.5262 * * * \\
(12.3841)\end{array}$ & $\begin{array}{l}5.5186^{* * *} \\
(12.7315)\end{array}$ & $\begin{array}{l}5.4126^{* * *} \\
(12.3574)\end{array}$ & $\begin{array}{l}5.4683^{* * *} \\
(12.0235)\end{array}$ & $\begin{array}{l}5.3390^{* * *} \\
(11.6218)\end{array}$ & $\begin{array}{l}5.4957^{* * *} \\
(12.4062)\end{array}$ & $\begin{array}{l}5.3839^{* * *} \\
(12.0047)\end{array}$ \\
\hline Roa & $\begin{array}{l}-19.7916 \\
(-0.7460)\end{array}$ & $\begin{array}{c}1.1681 \\
(1.0912)\end{array}$ & $\begin{array}{l}10.5686 \\
(0.8800)\end{array}$ & $\begin{array}{l}10.2046 \\
(0.8444)\end{array}$ & $\begin{array}{c}5.0166 \\
(0.4079)\end{array}$ & $\begin{array}{c}4.5938 \\
(0.3717)\end{array}$ & $\begin{array}{l}10.6986 \\
(0.9059)\end{array}$ & $\begin{array}{l}10.3528 \\
(0.8717)\end{array}$ \\
\hline Lev & $\begin{array}{l}10.9356 \\
(1.2935)\end{array}$ & $\begin{array}{c}0.0970 \\
(0.3072)\end{array}$ & $\begin{array}{c}0.4932 \\
(0.1458)\end{array}$ & $\begin{array}{c}1.3948 \\
(0.4103)\end{array}$ & $\begin{array}{c}0.3532 \\
(0.1023)\end{array}$ & $\begin{array}{c}1.3559 \\
(0.3921)\end{array}$ & $\begin{array}{c}0.2088 \\
(0.0607)\end{array}$ & $\begin{array}{c}1.1018 \\
(0.3175)\end{array}$ \\
\hline Growth & $\begin{array}{c}0.3819 \\
(0.1065)\end{array}$ & $\begin{array}{c}-0.3754^{* *} \\
(-2.2965)\end{array}$ & $\begin{array}{c}-3.4446^{* *} \\
(-2.0594)\end{array}$ & $\begin{array}{c}-3.5849 * * \\
(-2.1418)\end{array}$ & $\begin{array}{l}-3.6258^{* *} \\
(-2.1600)\end{array}$ & $\begin{array}{l}-3.7386^{* *} \\
(-2.2216)\end{array}$ & $\begin{array}{c}-3.6628^{* *} \\
(-2.1740)\end{array}$ & $\begin{array}{c}-3.8066^{* *} \\
(-2.2779)\end{array}$ \\
\hline Loss & $\begin{array}{l}-6.1806^{*} \\
(-1.6641)\end{array}$ & $\begin{array}{c}-0.3726^{* *} \\
(-2.2140)\end{array}$ & $\begin{array}{c}-4.3474 * * \\
(-2.3937)\end{array}$ & $\begin{array}{c}-4.3099 * * \\
(-2.3971)\end{array}$ & $\begin{array}{l}-4.0795^{* *} \\
(-2.2923)\end{array}$ & $\begin{array}{l}-4.0976^{* *} \\
(-2.3232)\end{array}$ & $\begin{array}{c}-4.0617^{* *} \\
(-2.3775)\end{array}$ & $\begin{array}{c}-4.0364^{* *} \\
(-2.3899)\end{array}$ \\
\hline Ndual & $\begin{array}{c}-4.0031 \\
(-1.5685)\end{array}$ & $\begin{array}{l}-0.2386 * \\
(-1.7964)\end{array}$ & & & $\begin{array}{c}-4.2776^{* * *} \\
(-3.1112)\end{array}$ & $\begin{array}{c}-4.1286^{* * *} \\
(-3.0153)\end{array}$ & $\begin{array}{c}-3.7575 * * * \\
(-2.6181)\end{array}$ & $\begin{array}{c}-3.6279^{* *} \\
(-2.5337)\end{array}$ \\
\hline$I d r$ & $\begin{array}{l}-23.9538 \\
(-1.1459)\end{array}$ & $\begin{array}{c}-0.0214 \\
(-0.0268)\end{array}$ & & & $\begin{array}{c}2.8759 \\
(0.3413) \\
\end{array}$ & $\begin{array}{c}2.9886 \\
(0.3610) \\
\end{array}$ & $\begin{array}{c}0.1056 \\
(0.0126) \\
\end{array}$ & $\begin{array}{c}0.4623 \\
(0.0562) \\
\end{array}$ \\
\hline Rate & $\begin{array}{c}-0.2079 \\
(-0.0794)\end{array}$ & $\begin{array}{c}-0.0300 \\
(-0.2300)\end{array}$ & $\begin{array}{c}-0.5673 \\
(-0.4066)\end{array}$ & $\begin{array}{c}-0.7551 \\
(-0.5420)\end{array}$ & $\begin{array}{c}-0.7408 \\
(-0.5324)\end{array}$ & $\begin{array}{c}-0.8997 \\
(-0.6486)\end{array}$ & $\begin{array}{c}-0.5379 \\
(-0.4324)\end{array}$ & $\begin{array}{c}-0.7212 \\
(-0.5791) \\
\end{array}$ \\
\hline $\operatorname{Reg}$ & & & & & $\begin{array}{c}0.9591 \\
(1.5985)\end{array}$ & $\begin{array}{c}0.8567 \\
(1.4179)\end{array}$ & & \\
\hline Pub & & & & & $\begin{array}{c}2.0842 * * * \\
(3.0119)\end{array}$ & $\begin{array}{c}2.1381 * * * \\
(3.0758)\end{array}$ & & \\
\hline$M d i$ & & & & & $\begin{array}{c}1.4588 \\
(0.8967)\end{array}$ & $\begin{array}{c}1.8090 \\
(1.1188)\end{array}$ & & \\
\hline For & & & & & $\begin{array}{c}2.8362 \\
(0.4761)\end{array}$ & $\begin{array}{c}1.2416 \\
(0.2091)\end{array}$ & & \\
\hline _Cons & $\begin{array}{c}-1.5 \times 10^{2} * * * \\
(-3.4401)\end{array}$ & & $\begin{array}{c}-86.2033^{* * *} \\
(-6.3608)\end{array}$ & $\begin{array}{c}-77.4732 \text { *** } \\
(-5.6611)\end{array}$ & $\begin{array}{c}-98.8962 * * * \\
(-5.6729)\end{array}$ & $\begin{array}{c}-91.9078^{* * *} \\
(-5.2345)\end{array}$ & $\begin{array}{c}-87.2054^{* * *} \\
(-6.2471)\end{array}$ & $\begin{array}{c}-78.5680 * * * \\
(-5.4851)\end{array}$ \\
\hline Ind & Control & Control & Control & Control & Control & Control & Control & Control \\
\hline Year & Control & Control & Control & Control & Control & Control & Control & Control \\
\hline $\begin{array}{c}\text { Statistics } \\
1\end{array}$ & $\begin{array}{c}4.5703^{*} \\
(p=0.0910)\end{array}$ & & & & & & & \\
\hline $\begin{array}{c}\text { Statistics } \\
2 \\
\end{array}$ & $\begin{array}{c}0.0525 \\
(p=0.8054)\end{array}$ & & & & & & & \\
\hline$N$ & 1599 & 1603 & 1613 & 1613 & 1603 & 1603 & 1603 & 1603 \\
\hline$R^{2}$ & 0.5472 & 0.0555 & 0.2008 & 0.2044 & 0.2149 & 0.2182 & 0.2022 & 0.2057 \\
\hline
\end{tabular}

Note: Statistics 1 is Kleibergen- Paap rk M, Statistics 2 is Hansen J. ${ }^{* * *}, * *, *$ indicates $p<0.01, p<0.05$, and $p<0.1$, respectively.

2. After sorting Green and Icr from low to high and then dividing them into 10 equal parts, we then used the multiple Logit model, expressed in terms of probability. The results indicate that the coefficient of Icr is significantly positive $(p<0.05)$, which again validates our stated proposition.

3. Because the main explanatory variable, Icr, is measured using the five components of internal control, firm governance variables might have been included in the internal control index. OLS 
regression was repeated after deleting the firm governance-related control variables (Ndual and $I d r)$, reaching the same conclusions.

4. Although some studies have found that external pressure weakly influences the environmental information disclosure of Chinese listed companies [10,13,51], in order to ensure the robustness of our conclusions, we added control variables related to external pressure. Environmental regulatory pressure was measured by the number of environmental administrative punishment cases at the location (province) of the firm (Reg); the pressure of public participation was measured by the number of proposals related to environmental issues at the location of the firm $(P u b)$; and the pressure of media reporting was measured by whether the company had received negative environmental media attention in the current year $(M d i)$. Morever, we chose the proportion of imported foreign investment scale divided by GDP during that year in the location of the company as a proxy variable of the share of foreign owners (For). After the related control variables were added, the regression coefficients remained the same.

5. Using Bootstrap's self-sampling method, the sample was randomly sampled 300 times with replacement, the sample size was expanded, and OLS regression was performed to recalculate the standard error of the key explanatory variables. The results indicate that Icr was significantly positive $(p<0.05)$, and that Icminus was significantly negative $(p<0.01)$, indicating that the conclusions of this paper are robust.

\section{Discussion}

In order to examine how internal control affects the firm greenness level, we conducted research on the following issues.

\subsection{The Nature of Property Rights}

In China, the actual controller of state-owned firms is the people's government at all levels. The will of the government determines the behavior of state-owned firms. According to the requirements of the central government's Guiding Opinions on State-owned Enterprises to Better Perform Social Responsibility, state-owned firms are more likely to play a leading role in environmental and social responsibility. Table 8 shows the results of a grouping test according to the property rights of firms. In the sub-sample of state-owned firms, the coefficient of Icr is significantly positive $(p<0.01)$; the coefficient of Icminus is significantly negative $(p<0.01)$; and the coefficient of the non-state-owned sub-sample was not significant for either Icr or Icminus. This indicates that the promotion effect of internal control on the firm greenness is chiefly reflected in state-owned firms. These findings also support the literature that state-owned firms give more concern of environmental information disclosure $[9,12,13]$.

Table 8. Test based on nature of property rights.

\begin{tabular}{ccccc}
\hline \multirow{2}{*}{ Green } & State-Owned Firm & Non-State-Owned Firm & State-Owned Firm & Non-State-Owned Firm \\
\cline { 2 - 5 } & $\mathbf{( 1 )}$ & $\mathbf{( 2 )}$ & $\mathbf{( 3 )}$ & $\mathbf{( 4 )}$ \\
\hline \multirow{2}{*}{ Icr } & $0.1968^{* * *}$ & -0.1172 & & -0.9679 \\
& $(2.6909)$ & $(-0.8420)$ & $-3.9437^{* * *}$ & $(-0.4931)$ \\
\hline \multirow{2}{*}{ Icminus } & & & $(-2.9441)$ & $5.3253^{* *}$ \\
\hline \multirow{2}{*}{ Lnpgdp } & 0.7666 & $5.6921^{* *}$ & 0.6805 & $(2.0247)$ \\
\hline \multirow{2}{*}{ Lnasset } & $(0.5988)$ & $(2.1646)$ & $(0.5310)$ & $5.8870 * *$ \\
\hline \multirow{2}{*}{ Roa } & $5.6960 * * *$ & $5.9457^{* * *}$ & $5.5882 * * *$ & $(5.1554)$ \\
\hline \multirow{2}{*}{ Lev } & $(11.4396)$ & $(5.2596)$ & $(11.0938)$ & -14.0709 \\
\hline & $28.6511^{* *}$ & -12.4760 & $27.4131^{*}$ & $(-0.7062)$ \\
\hline
\end{tabular}


Table 8. Cont.

\begin{tabular}{ccccc}
\hline \multirow{2}{*}{ Green } & State-Owned Firm & Non-State-Owned Firm & State-Owned Firm & Non-State-Owned Firm \\
\cline { 2 - 5 } & $\mathbf{( 1 )}$ & $\mathbf{( 2 )}$ & $\mathbf{( 3 )}$ & $\mathbf{4})$ \\
\hline \multirow{2}{*}{ Growth } & $-3.2814^{*}$ & -1.1690 & $-3.6404^{*}$ & -1.2201 \\
& $(-1.7032)$ & $(-0.4400)$ & $(-1.8753)$ & $(-0.4570)$ \\
\hline \multirow{2}{*}{ Loss } & $-3.3538^{*}$ & -5.6143 & $-3.4084^{*}$ & -5.8422 \\
& $(-1.6470)$ & $(-1.4774)$ & $(-1.6841)$ & $(-1.5418)$ \\
\hline \multirow{2}{*}{ Ndual } & -1.1126 & $-5.0503^{* *}$ & -0.9940 & $-5.0727^{* *}$ \\
& $(-0.6161)$ & $(-2.4762)$ & $(-0.5450)$ & $(-2.4921)$ \\
\hline \multirow{2}{*}{ Idr } & $-20.0229^{* *}$ & 25.2593 & $-18.1736^{*}$ & 24.0358 \\
& $(-1.9805)$ & $(1.5651)$ & $(-1.8016)$ & $(1.5087)$ \\
\hline \multirow{2}{*}{ Rate } & -1.5549 & 1.2032 & -1.7969 & 1.2206 \\
& $(-0.9247)$ & $(0.4157)$ & $(-1.0690)$ & $(0.4208)$ \\
\hline \multirow{2}{*}{ Cons } & $-82.7762^{* * *}$ & $-1.3 \times 10^{2 * * *}$ & $-74.3703 * * *$ & $-1.3 \times 10^{2 * * *}$ \\
& $(-5.2792)$ & $(-3.8121)$ & $(-4.7108)$ & $(-3.6734)$ \\
\hline Ind & Control & Control & Control & Control \\
\hline Year & Control & Control & Control & Control \\
\hline $\mathrm{N}$ & 1089 & 514 & 1089 & 514 \\
\hline Adj. $\mathrm{R}^{2}$ & 0.2314 & 0.1519 & 0.2329 & 0.1509 \\
\hline \multirow{2}{*}{ Note: ${ }^{* * * * *, *}$ indicates $p<0.01, p<0.05$, and $p<0.1$, respectively. } &
\end{tabular}

\subsection{The Five Components of Internal Control}

The impact of the five components of internal control on the firm greenness was further examined. As columns 1-5 in Table 9 indicate, the coefficient of the internal environment and the coefficient of information and communication were significantly positive ( $p<0.01$ and $p<0.05$, respectively). The coefficients for the other components were positive but not significant. This indicates that a good governance structure and firm culture can improve the authenticity of firm environmental information disclosure, and promote the performance of firm environmental protection responsibilities. Furthermore, an effective information and communication mechanism can aid in the transmission of financial information and non-financial information within the firm, or between the firm and the outside world, prevent misstatements and omissions, and ensure that the environmental information disclosed is objective and truthful to the greatest extent. The above findings comport with the conclusions of previous context, because just as noted in COSO of 2004, the various components in the firm internal control system were closely linked and interacting, and their effectiveness depends on the overall operating efficacy of the system rather than the individual components.

Table 9. Test-based components and rectification.

\begin{tabular}{|c|c|c|c|c|c|c|}
\hline \multirow[t]{2}{*}{ Green } & \multirow{2}{*}{$\begin{array}{c}\begin{array}{c}\text { Internal } \\
\text { Environment }\end{array} \\
\text { (1) }\end{array}$} & \multirow{2}{*}{$\begin{array}{c}\text { Risk } \\
\text { Assessment } \\
(2)\end{array}$} & \multirow{2}{*}{$\begin{array}{c}\begin{array}{c}\text { Control } \\
\text { Activities }\end{array} \\
\text { (3) }\end{array}$} & \multicolumn{2}{|c|}{$\begin{array}{lc}\text { Information } & \text { Internal } \\
\text { and } & \text { Supervision } \\
\text { Communication }\end{array}$} & \multirow{2}{*}{$\begin{array}{c}\text { Rectification of } \\
\text { Deficiencies }\end{array}$} \\
\hline & & & & (4) & (5) & \\
\hline Icr & $\begin{array}{c}0.4102 * * * \\
(2.7463)\end{array}$ & $\begin{array}{c}0.3842 \\
(1.3333)\end{array}$ & $\begin{array}{c}0.0727 \\
(0.4510)\end{array}$ & $\begin{array}{l}0.8604 * * \\
(2.0956)\end{array}$ & $\begin{array}{c}0.0729 \\
(0.4582)\end{array}$ & \\
\hline L.icminus & & & & & & $\begin{array}{l}-3.0193^{* *} \\
(-2.4527)\end{array}$ \\
\hline Icrevi & & & & & & $\begin{array}{l}2.7163 * \\
(1.6583)\end{array}$ \\
\hline Lnpgdp & $\begin{array}{c}1.3098 \\
(1.1555)\end{array}$ & $\begin{array}{c}1.4507 \\
(1.2787)\end{array}$ & $\begin{array}{c}1.4974 \\
(1.3184)\end{array}$ & $\begin{array}{c}1.4995 \\
(1.3230)\end{array}$ & $\begin{array}{c}1.5275 \\
(1.3495)\end{array}$ & $\begin{array}{c}1.0828 \\
(0.8559)\end{array}$ \\
\hline Lnasset & $\begin{array}{l}5.5216^{* * *} \\
(12.4853)\end{array}$ & $\begin{array}{l}5.4802 * * * \\
(12.4481)\end{array}$ & $\begin{array}{l}5.5213 * * * \\
(12.4651)\end{array}$ & $\begin{array}{l}5.5331 \text { *** } \\
(12.4944)\end{array}$ & $\begin{array}{l}5.4913 * * * \\
(12.4445)\end{array}$ & $\begin{array}{l}5.6627 * * * \\
(11.6605)\end{array}$ \\
\hline Roa & $\begin{array}{l}10.7112 \\
(0.8743)\end{array}$ & $\begin{array}{l}11.6191 \\
(0.9536)\end{array}$ & $\begin{array}{l}11.4250 \\
(0.9308)\end{array}$ & $\begin{array}{l}11.5241 \\
(0.9426)\end{array}$ & $\begin{array}{l}11.7812 \\
(0.9694)\end{array}$ & $\begin{array}{l}18.1216 \\
(1.2643)\end{array}$ \\
\hline
\end{tabular}


Table 9. Cont.

\begin{tabular}{|c|c|c|c|c|c|c|}
\hline Green & $\begin{array}{c}\text { Internal } \\
\text { Environment }\end{array}$ & $\begin{array}{c}\text { Risk } \\
\text { Assessment }\end{array}$ & $\begin{array}{c}\text { Control } \\
\text { Activities }\end{array}$ & $\begin{array}{l}\text { Information } \\
\text { and } \\
\text { Communication }\end{array}$ & $\begin{array}{c}\text { Internal } \\
\text { Supervision }\end{array}$ & $\begin{array}{c}\text { Rectification of } \\
\text { Deficiencies }\end{array}$ \\
\hline & (1) & (2) & (3) & (4) & (5) & (6) \\
\hline Lev & $\begin{array}{c}0.0113 \\
(0.0033) \\
\end{array}$ & $\begin{array}{c}-0.1242 \\
(-0.0361) \\
\end{array}$ & $\begin{array}{c}-0.0621 \\
(-0.0181) \\
\end{array}$ & $\begin{array}{c}-0.1612 \\
(-0.0467) \\
\end{array}$ & $\begin{array}{l}-0.1064 \\
(-0.0309) \\
\end{array}$ & $\begin{array}{l}1.7576 \\
(0.4552) \\
\end{array}$ \\
\hline Growth & $\begin{array}{l}-3.5641 \text { ** } \\
(-2.1341)\end{array}$ & $\begin{array}{l}-3.7171^{* *} \\
(-2.2055)\end{array}$ & $\begin{array}{l}-3.7915^{\text {*** }} \\
(-2.2443)\end{array}$ & $\begin{array}{l}-3.7971^{* *} \\
(-2.2555)\end{array}$ & $\begin{array}{l}-3.8047^{* *} \\
(-2.2555)\end{array}$ & $\begin{array}{l}-3.9051 \text { ** } \\
(-2.3542)\end{array}$ \\
\hline Loss & $\begin{array}{l}-3.9769 * * \\
(-2.1987) \\
\end{array}$ & $\begin{array}{l}-3.9530 * * \\
(-2.1730) \\
\end{array}$ & $\begin{array}{l}-4.0257^{* *} \\
(-2.2039)\end{array}$ & $\begin{array}{c}-4.0638^{* *} \\
(-2.2371)\end{array}$ & $\begin{array}{c}-3.9916^{* *} \\
(-2.1961)\end{array}$ & $\begin{array}{l}-3.3690 * \\
(-1.7290)\end{array}$ \\
\hline Ndual & $\begin{array}{l}-3.6236^{* * *} \\
(-2.6669)\end{array}$ & $\begin{array}{c}-3.7928^{* * *} \\
(-2.7769)\end{array}$ & $\begin{array}{c}-3.7618^{* * *} \\
(-2.7585)\end{array}$ & $\begin{array}{c}-3.9140 * * * \\
(-2.8570)\end{array}$ & $\begin{array}{c}-3.7399 * * * \\
(-2.7401)\end{array}$ & $\begin{array}{l}-3.6739 * * \\
(-2.3564)\end{array}$ \\
\hline$I d r$ & $\begin{array}{c}-1.1741 \\
(-0.1402) \\
\end{array}$ & $\begin{array}{c}1.3057 \\
(0.1569)\end{array}$ & $\begin{array}{c}0.8044 \\
(0.0966)\end{array}$ & $\begin{array}{c}0.8451 \\
(0.1017) \\
\end{array}$ & $\begin{array}{c}0.9493 \\
(0.1142) \\
\end{array}$ & $\begin{array}{l}13.1408 \\
(1.4642) \\
\end{array}$ \\
\hline Rate & $\begin{array}{l}-0.4930 \\
(-0.3551)\end{array}$ & $\begin{array}{c}-0.5148 \\
(-0.3696)\end{array}$ & $\begin{array}{c}-0.5462 \\
(-0.3909)\end{array}$ & $\begin{array}{c}-0.6362 \\
(-0.4581)\end{array}$ & $\begin{array}{l}-0.5594 \\
(-0.4011)\end{array}$ & $\begin{array}{l}-1.7613 \\
(-1.0908)\end{array}$ \\
\hline _Cons & $\begin{array}{c}-87.5386^{* * *} \\
(-6.3086)\end{array}$ & $\begin{array}{c}-84.6150^{* * *} \\
(-6.1156)\end{array}$ & $\begin{array}{c}-85.4706^{* * *} \\
(-6.1551)\end{array}$ & $\begin{array}{c}-87.0849^{* * *} \\
(-6.2494)\end{array}$ & $\begin{array}{c}-85.0354 * * * \\
(-6.1417)\end{array}$ & $\begin{array}{c}-94.5979^{* * *} \\
(-6.0187)\end{array}$ \\
\hline Ind & Control & Control & Control & Control & Control & Control \\
\hline Year & Control & Control & Control & Control & Control & Control \\
\hline $\mathrm{N}$ & 1603 & 1603 & 1603 & 1603 & 1603 & 1291 \\
\hline Adj. $R^{2}$ & 0.2037 & 0.2007 & 0.2000 & 0.2021 & 0.2000 & 0.2239 \\
\hline
\end{tabular}

\subsection{Internal Control Deficiency Rectification}

Next, we examined how rectification of major deficiencies in internal control affects firm greenness. Drawing on the research of [74], if the company had major internal control deficiencies in the previous year, the value of Icminus with one lag period (L.icminus) is 1 ; otherwise 0 . If the company subsequently declared in the internal control evaluation report that there were no unrectified major deficiencies in the internal control, the value of Icrevi was 1; otherwise 0 . As the results in column 6 in Table 9 show, the L.icminus coefficient was significantly negative $(p<0.05)$, indicating that compared with companies that do not have substantial deficiencies in internal control, the environmental information disclosure has a lower level of greenness in companies with uncorrected major deficiencies in internal control. The coefficient of icrevi was 2.7163 , which was significantly positive $(p<0.1)$, indicating that after controlling for the characteristics of companies that affect environmental information disclosure, companies that have improved one of the material deficiencies in internal control, the effect on the increased level of greenness is 2.7163 .

\section{Conclusions}

In China, the Ministry of Environmental Protection and both the Shanghai and Shenzhen Stock Exchanges successively have issued a series of policy documents to strengthen environment information disclosure of listed companies. This brings about system pressure on enterprises to disclosure environmental information. Most of the time, benefits brought about by an enterprise's compliance with the system may not be obvious, but losses caused by non-compliance are obvious. Therefore, the enterprise will respond to external pressure ritually with explicit behavior, which conforms to the expectation of legitimacy theory. However, actually, during the information disclosure, enterprises may adopt modes of "reporting only what is good while concealing what is unpleasant" and "more words and less actions" to comply with requirements of environmental regulations. This kind of greenwashing is secretive, which creates the difficulty of environmental supervision. Apart from being affected by external mechanisms such as environmental legality, environmental information disclosure 
level is also affected by the internal governance level within an enterprise. The paper's research interest is to investigate whether internal control, as an important internal mechanism, positively affects the environmental information disclosure level of enterprises.

We studied the listed companies in heavily polluting industries of the Chinese capital market. Results indicate that when other conditions did not change, the higher the quality of the firm internal control, the higher the level of authenticity of the environmental information disclosure. This finding confirms our stated proposition that the level of internal control positively affects a firm's green information disclosure. After the investigating the influence of endogenous factors and conducting tests of robustness, the above conclusions remained unchanged. Further research indicates that the role of internal control in promoting firm greenness was mainly evidenced in state-owned firms. The internal environment as well as information and communication components of internal control had a significant positive impact on the actual performance of firm environmental responsibility. Rectification of major deficiencies in internal control helped improve the authenticity of firm environmental information disclosure.

The internal control within China's internal control regulatory system involves both financial reporting and non-financial reporting. This is significantly different from the SOX Act, which focuses only on the internal control of financial reporting. Our research indicates that compared with the United States after the SOX Act of 2002, the construction of China's firm internal control is more in line with the original intention of the existing theoretical framework of COSO and the actual needs of stakeholders. However, because of the difficulty in its implementation and operational costs, challenges were raised about the effectiveness of the system. Thus, this paper holds strong theoretical value and practical significance for testifying to the effectiveness of the Chinese internal control system.

The marginal contributions of this study are as follows:

First, existing research extensively discusses the effectiveness of internal control from the perspectives of accrual quality, accounting prudence, audit efficiency, and financial restatement [74-79]. The relevant empirical studies answered questions about the impact of internal control on the reliability of financial reporting. Although the 2004 COSO report proposed reliability goals covering non-financial information, few studies have explored the economic consequences of internal control from the perspective of non-financial information. This study provides empirical evidence for a comprehensive understanding of the reporting goals of firm internal control, expands the vitality of internal control, and indicates that the Chinese government's commitment to the internal control system standardization in recent years has important practical significance. Second, existing empirical research indicates that external pressure and internal governance are important factors affecting firm social responsibility information disclosure [34]. Although the relevant results are rich, there has been a lack of deep exploration on whether internal control has a significant impact on environmental information disclosure. This study enriches the literature on the impact of internal governance mechanisms on firm environmental information disclosure. The conclusions of this study also add useful empirical evidence for governance on greenwashing, which has important reference value for promoting the execution of environmental protection responsibilities of listed companies.

China has a typical emerging and transitional economy. Contradictions between economic growth and environmental protection are relatively outstanding and environmental regulation may be forced to give way to pressure for economic development by local government. This is what many developing countries are facing or are about to face. However, green development needs the enterprise's internal motivational mechanism. Our research supports establishing a sound internal control standards system to not only ensure the reliability of financial reporting, but also to help improve the authenticity and transparency of non-financial information disclosures, such as environmental and social responsibility, and promote the firm's actual performance. The paper enriched the literature by providing supporting evidence that internal control plays an important guiding and monitoring role in the performance of a firm's environmental responsibilities. Thus, construction and operation of internal control has a significant and far-reaching impact on the protection of stakeholders' rights and interests. This paper 
also provides a theoretical basis for the Chinese government to adhere to a comprehensive internal control standards system and continuously improve the quality of internal control of listed companies. The research of this paper also provides useful enlightenment for other developing countries to carry out the construction of internal control system norms in combination with their own situations.

The paper may have the following limitations: Firstly, the paper selects listed companies in heavy polluting industries as research objects. Although the objects are typical, they cannot represent the overall condition of all environment information disclosure of China's listed companies. Secondly, enterprise environment information disclosure is affected by various internal and external factors. Due to data availability, in the studies in the paper there may exist uncontrolled factors such as: the composition of stakeholders and the individual characters of senior management. The influence of those factors is to be further studied.

Author Contributions: Conceptualization, R.H.; methodology, R.H.; software, Y.H.; formal analysis, R.H.; investigation, R.H., Y.H.; data curation, R.H., Y.H.; writing-original draft preparation, R.H.; writing-review and editing, R.H.; funding acquisition, R.H. All authors have read and agreed to the published version of the manuscript.

Funding: This research is supported by Key Research Projects of the National Social Science Foundation of China (Grant No. 17AGL019).

Acknowledgments: We are indebted to the anonymous reviewers and editor.

Conflicts of Interest: The authors declare no conflict of interest.

\section{References}

1. Tietenberg, T.H. Disclosure Strategies for Pollution Control. Environ. Resour. Econ. 1998, 11, 587-602. [CrossRef]

2. Huang, R.; Chen, W.; Wang, K. External Financing Demand, Impression Management and Enterprise Greenwashing. Comp. Econ. Soc. Syst. 2019, 34, 81-93. (In Chinese)

3. Huang, R.; Chen, D. Does Environmental Information Disclosure Benefit Waste Discharge Reduction? Evidence from China. J. Bus. Ethics 2015, 129, 535-552. [CrossRef]

4. Deegan, C.; Gordon, B. A Study of the Environmental Disclosure Practices of Australian Corporations. Account. Bus. Res. 1996, 26, 187-199. [CrossRef]

5. Campbell, D. Intra- and Intersectoral Effects in Environmental Disclosures: Evidence for Legitimacy Theory? Bus. Strategy Environ. 2003, 12, 357-371. [CrossRef]

6. Darnall, N.; Henriques, I.; Sadorsky, P. Adopting Proactive Environmental Strategy: The Influence of Stakeholders and Firm Size. J. Manag. Stud. 2010, 47, 1072-1094. [CrossRef]

7. Al-Tuwaijri, S.A.; Christensen, T.E.; Hughes, K.E. The Relations among Environmental Disclosure, Environmental Performance, and Economic Performance: A Simultaneous Equations Approach. Account. Organ. Soc. 2004, 29, 447-471. [CrossRef]

8. Tagesson, T.; Blank, V.; Broberg, P.; Collin, S. What Explains the Extent and Content of Social and Environmental Disclosures on Corporate Websites: A Study of Social and Environmental Reporting in Swedish Listed Corporatons. Corp. Soc. Responsib. Environ. Manag. 2009, 16, 352-364. [CrossRef]

9. Meng, X.H.; Zeng, S.X.; Tam, C.M. From Voluntarism to Regulation: A Study on Ownership, Economic Performance and Corporate Information Disclosure in China. J. Bus. Ethics 2013, 116, 217-232. [CrossRef]

10. Lu, Y.; Abeysekera, I. Stakeholders' Power, Corporate Characteristics, and Social and Environmental Disclosure: Evidence from China. J. Clean. Prod. 2014, 64, 426-436. [CrossRef]

11. Mohd Ghazali, N.A. Ownership Structure and Corporate Social Responsibility Disclosure: Some Malaysian Evidence. Corp. Gov. Int. J. Bus. Soc. 2007, 7, 251-266. [CrossRef]

12. Kuo, L.; Yeh, C.C.; Yu, H.C. Disclosure of Corporate Social Responsibility and Environmental Management: Evidence from China. Corp. Soc. Responsib. Environ. Manag. 2012, 19, 273-287. [CrossRef]

13. Zeng, S.X.; Xu, X.D.; Yin, H.T.; Tam, C.M. Factors that Drive Chinese Listed Companies in Voluntary Disclosure of Environmental Information. J. Bus. Ethics 2012, 109, 309-321. [CrossRef] 
14. Cheng, Z.; Wang, F.; Keung, C.; Bai, Y. Will Corporate Political Connection Influence the Environmental Information Disclosure Level? Based on the Panel Data of A-Shares from Listed Companies in Shanghai Stock Market. J. Bus. Ethics 2017, 143, 209-221. [CrossRef]

15. Brammer, S.; Pavelin, S. Voluntary Environmental Disclosures by Large UK Companies. J. Bus. Financ. Account. 2006, 33, 1168-1188. [CrossRef]

16. Iatridis, G.E. Environmental Disclosure Quality: Evidence on Environmental Performance, Corporate Governance and Value Relevance. Emerg. Mark. Rev. 2013, 14, 55-75. [CrossRef]

17. Ortas, E.; Gallego-Alvarez, I.; Álvarez Etxeberria, I. Financial Factors Influencing the Quality of Corporate Social Responsibility and Environmental Management Disclosure: A Quantile Regression Approach. Corp. Soc. Responsib. Environ. Manag. 2015, 22, 362-380. [CrossRef]

18. Kouloukoui, D.; Sant'Anna, Â.M.O.; Silva, G.S. Factors Influencing the Level of Environmental Disclosures in Sustainability Reports: Case of Climate Risk Disclosure by Brazilian Companies. Corp. Soc. Responsib. Environ. Manag. 2019, 26, 791-804. [CrossRef]

19. Jose, A.; Lee, S. Environmental Reporting of Global Corporations: A Content Analysis Based on Website Disclosures. J. Bus. Ethics 2007, 72, 307-321. [CrossRef]

20. García-Ayuso, M.; Larrinaga, C. Environmental Disclosure in Spain: Corporate Characteristics and Media Exposure. Span. J. Financ. Account. Rev. Española Financ. Contab. 2003, 32, 184-214.

21. Brammer, S.; Pavelin, S. Factors Influencing the Quality of Corporate Environmental Disclosure. Bus. Strategy Environ. 2008, 17, 120-136. [CrossRef]

22. Clarkson, P.M.; Overell, M.B.; Chappel, L. Environmental Reporting and Its Relation to Corporate Environmental Performance. Abacus 2011, 47, 27-60. [CrossRef]

23. Khan, A.; Muttakin, M.B.; Siddiqui, J. Corporate Governance and Corporate Social Responsibility Disclosure: Evidence from an Emerging Economy. J. Bus. Ethics 2013, 114, 207-223. [CrossRef]

24. Peters, G.F.; Romi, A.M. Does the Voluntary Adoption of Corporate Governance Mechanisms Improve Environmental Risk Disclosures? Evidence from Greenhouse Gas Emission Accounting. J. Bus. Ethics 2014, 125, 637-666. [CrossRef]

25. Liao, L.; Luo, L.; Tang, Q. Gender Diversity, Board Independence, Environmental Committee and Greenhouse Gas Disclosure. Br. Account. Rev. 2015, 47, 409-424. [CrossRef]

26. Mahmood, Z.; Kouser, R.; Ali, W.; Ahmad, Z.; Salman, T. Does Corporate Governance Affect Sustainability Disclosure? A Mixed Methods Study. Sustainability 2018, 10, 207. [CrossRef]

27. Giannarakis, G.; Andronikidis, A.; Sariannidis, N. Determinants of Environmental Disclosure: Investigating New and Conventional Corporate Governance Characteristics. Ann. Oper. Res. 2019, 1-19. [CrossRef]

28. Lagasio, V.; Cucari, N. Corporate Governance and Environmental Social Governance Disclosure: A Meta-Analytical Review. Corp. Soc. Responsib. Environ. Manag. 2019, 26, 701-711. [CrossRef]

29. Pucheta-Martínez, M.C.; López-Zamora, B. Engagement of Directors Representing Institutional Investors on Environmental Disclosure. Corp. Soc. Responsib. Environ. Manag. 2018, 25, 1108-1120. [CrossRef]

30. Lewis, B.W.; Walls, J.L.; Dowell, G.W. Difference in Degrees: CEO Characteristics and Firm Environmental Disclosure. Strateg. Manag. J. 2014, 35, 712-722. [CrossRef]

31. Meng, X.H.; Zeng, S.X.; Tam, C.M.; Xu, X.D. Whether Top Executives' Turnover Influence Environmental Responsibility: From the Perspective of Environmental Information Disclosure. J. Bus. Ethics 2013, 114, 341-353. [CrossRef]

32. Cho, C.H.; Patten, D.M. The Role of Environmental Disclosure as Tools of Legitimacy: A Research Note. Account. Organ. Soc. 2007, 32, 639-647. [CrossRef]

33. De Villiers, C.; Van Staden, C.J. Can Less Environmental Disclosure Have a Legitimising Effect? Evidence from Africa. Account. Organ. Soc. 2006, 31, 763-781. [CrossRef]

34. Fifka, M.S. Corporate Responsibility Reporting and its Determinants in Comparative Perspective-A Review of the Empirical Literature and a Meta-analysis. Bus. Strategy Environ. 2013, 22, 1-35. [CrossRef]

35. Yao, S.; Liang, H. Firm Location, Political Geography and Environmental Information Disclosure. Appl. Econ. 2017, 49, 251-262. [CrossRef]

36. Li, D.; Huang, M.; Ren, S.; Chen, X.; Ning, L. Environmental Legitimacy, Green Innovation, and Corporate Carbon Disclosure: Evidence from CDP China 100. J. Bus. Ethics 2018, 150, 1089-1104. [CrossRef]

37. D'Amico, E.; Coluccia, D.; Fontana, S.; Solimene, S. Factors Influencing Corporate Environmental Disclosure. Bus. Strategy Environ. 2016, 25, 178-192. [CrossRef] 
38. Hoang, P.C.; Mcguire, W.; Prakash, A. Reducing Toxic Chemical Pollution in Response to Multiple Information Signals: The 33/50 Voluntary Program and Toxicity Disclosures. Ecol. Econ. 2018, 146, 193-202. [CrossRef]

39. Barakat, F.S.Q.; López Pérez, M.V.; Rodríguez Ariza, L. Corporate Social Responsibility Disclosure (CSRD) Determinants of Listed Companies in Palestine (PXE) and Jordan (ASE). Rev. Manag. Sci. 2015, 9, 681-702. [CrossRef]

40. Chelli, M.; Durocher, S.; Fortin, A. Normativity in Environmental Reporting: A Comparison of Three Regimes. J. Bus. Ethics 2018, 149, 285-311. [CrossRef]

41. Cormier, D.; Magnan, M. The Economic Relevance of Environmental Disclosure and its Impact on Corporate Legitimacy: An Empirical Investigation. Bus. Strategy Environ. 2015, 24, 431-450. [CrossRef]

42. Walden, D.M.; Schwartz, B.N. Environmental Disclosures and Public Policy Pressure. J. Account. Public Policy 1997, 16, 125-154.

43. Heflin, F.; Wallace, D. The BP Oil Spill: Shareholder Wealth Effects and Environmental Disclosures. J. Bus. Financ. Account. 2017, 44, 337-374. [CrossRef]

44. Gao, S.; Ling, S.; Liu, W. The Role of Social Media in Promoting Information Disclosure on Environmental Incidents: An Evolutionary Game Theory Perspective. Sustainability 2018, 10, 4372. [CrossRef]

45. Aerts, W.; Cormier, D. Media Legitimacy and Corporate Environmental Communication. Account. Organ. Soc. 2009, 34, 1-27. [CrossRef]

46. Rupley, K.H.; Brown, D.; Marshall, R.S. Governance, Media and the Quality of Environmental Disclosure. J. Account. Public Policy 2012, 31, 610-640. [CrossRef]

47. Li, Q.; Li, T.; Chen, H.; Xiang, E.; Ruan, W. Executives' Excess Compensation, Legitimacy, and Dnvironmental Information Disclosure in Chinese Heavily Polluting Companies: The Moderating Role of Media Pressure. Corp. Soc. Responsib. Environ. Manag. 2019, 26, 248-256. [CrossRef]

48. Roberts, R.; Wallace, D. Sustaining Diversity in Social and Environmental Accounting Research. Crit. Perspect. Account. 2015, 32, 78-87. [CrossRef]

49. Li, H.; Zhou, L. Political Turnover and Economic Performance: The Incentive Role of Personnel Control in China. J. Public Econ. 2005, 89, 1743-1762. [CrossRef]

50. Wang, H.; Mamigi, N.; Laplante, B.; Dasgupa, S. Incomplete Enforcement of Pollution Regulation: Bargaining Power of Chinese Factories. Environ. Resour. Econ. 2003, 24, 255-273. [CrossRef]

51. Liu, X.; Anbumozhi, V. Determinant Factors of Corporate Environmental Information Disclosure: An Empirical Study of Chinese Listed Companies. J. Clean. Prod. 2009, 17, 593-600. [CrossRef]

52. Patten, D.M. The Accuracy of Financial Report Projections of Future Environmental Capital Expenditures: A Research Note. Account. Organ. Soc. 2005, 30, 457-468. [CrossRef]

53. Parguel, B.; Benoît-Moreau, F.; Larceneux, F. How Sustainability Ratings Might Deter 'Greenwashing': Closer Look at Ethical Corporate Communication. J. Bus. Ethics 2011, 102, 15-28. [CrossRef]

54. Walker, K.; Wan, F. The Harm of Symbolic Actions and Green-washing: Corporate Actions and Communications on Environmental Performance and Their Financial Implications. J. Bus. Ethics 2012, 109, 227-242. [CrossRef]

55. Neu, D.; Warsame, H.; Pedwell, K. Managing Public Impressions: Environmental Disclosure in Annual Reports. Account. Organ. Soc. 1998, 23, 265-282. [CrossRef]

56. Roulet, T.J.; Touboul, S. The Intentions with Which the Road is Paved: Attitudes to Liberalism as Determinants of Greenwashing. J. Bus. Ethics 2015, 128, 305-320. [CrossRef]

57. Laufer, W.S. Social Accountability and Corporate Greenwashing. J. Bus. Ethics 2003, 43, 253-261. [CrossRef]

58. Leonidou, C.N.; Leonidou, L.C. Research into Environmental Marketing/Management: A Bibliographic Analysis. Eur. J. Mark. 2011, 45, 68-103. [CrossRef]

59. Delmas, M.A.; Burbano, V.C. The Drivers of Greenwashing. Calif. Manag. Rev. 2011, 54, 64-87. [CrossRef]

60. Matejek, S.; Gössling, T. Beyond Legitimacy: A Case Study in BP's “Green Lashing”. J. Bus. Ethics 2014, 120, 571-584. [CrossRef]

61. Lyon, T.P.; Montgomery, A.W. Tweetjacked: The Impact of Social Media on Corporate Greenwash. J. Bus. Ethics 2013, 118, 747-757. [CrossRef]

62. Johnstone, K.; Li, C.; Rupley, K.H. Changes in Corporate Governance Associated with the Revelation of Internal Control Material Weakness and Their Subsequent Remediation. Contemp. Account. Res. 2011, 28, 331-381. [CrossRef] 
63. Moon, J.; Crane, A.; Matten, D. Can Corporations Be Citizens? Corporate Citizenship as a Metaphor for Business Participation in Society. Bus. Ethics Q. 2005, 15, 429-453. [CrossRef]

64. Doyle, J.T.; Ge, W.; McVay, S. Accruals Quality and Internal Control over Financial Reporting. Account. Rev. 2007, 82, 1141-1170. [CrossRef]

65. Clarkson, P.M.; Li, Y.; Richardson, G.D.; Vasvari, F.P. Revisiting the Relation between Environmental Performance and Environmental Disclosure: An Empirical Analysis. Account. Organ. Soc. 2008, 33, 303-327. [CrossRef]

66. Ashbaugh-Skaife, H.A.; Veenman, D.; Wangerin, D. Internal Control over Financial Reporting and Managerial Rent Extraction: Evidence from the Profitability of Insider Trading. J. Account. Econ. 2013, 55, 91-110. [CrossRef]

67. Li, Z. Internal Control and Environmental Information Disclosure: Evidence from Chinese Listed Manufacturing Firms. China Popul. Resour. Environ. 2014, 24, 77-83. (In Chinese)

68. Bowen, F.; Aragon-Correa, J. Greenwashing in Corporate Environmentalism Research and Practice: The Importance of What We Say and Do. Organ. Environ. 2014, 27, 107-112. [CrossRef]

69. Brennan, N.M.; Guillamon-Saorin, E.; Pierce, A. Methodological Insights: Impression Management: Developing and Illustrating a Scheme of Analysis for Narrative Disclosures-A Methodological Note. Account. Audit. Account. J. 2009, 225, 789-832. [CrossRef]

70. Lin, B.; Lin, D.; Xie, F.; Hu, W.; Yang, Y. Research of Internal Control Index on Information Disclosure. Account. Res. 2016, 36, 12-20. (In Chinese)

71. Fang, H.; Jin, Y. Corporate Governance, Internal Control and Inefficient Investment: Theoretical Analysis and Empirical Evidences. Account. Res. 2013, 33, 63-69. (In Chinese)

72. Liu, X.; Liu, Z. The Influence of Internal Control on Fair Value and Earnings Management. Audit. Res. 2014, 30, 59-66. (In Chinese)

73. Chen, J.; Xu, Y. Internal Control and Tax Aggression. Audit. Res. 2015, 30, 100-107. (In Chinese)

74. Ashbaugh-Skaife, H.; Collins, D.W.; Kinney, W.R.; LaFond, R. The Effect of SOX Internal Control Deficiencies and Their Remediation on Accrual Quality. Account. Rev. 2008, 83, 217-250. [CrossRef]

75. Goh, B.W.; Li, D. Internal Controls and Conditional Conservatism. Account. Rev. 2011, 86, 975-1005. [CrossRef]

76. Guo, J.; Huang, P.; Zhang, Y.; Zhou, N. The Effect of Employee Treatment Policies on Internal Control Weaknesses and Financial Restatements. Account. Rev. 2016, 91, 1167-1194. [CrossRef]

77. Lu, H.; Richardson, G.; Salterio, S. Direct and Indirect Effects of Internal Control Weaknesses on Accrual Quality: Evidence from a Unique Canadian Regulatory Setting. Contemp. Account. Res. 2011, 28, 675-707. [CrossRef]

78. Masli, A.; Peters, G.F.; Richardson, V.J.; Sanchez, J.M. Examining the Potential Benefits of Internal Control Monitoring Technology. Account. Rev. 2010, 85, 1001-1034. [CrossRef]

79. Mitra, S.; Jaggi, B.; Hossain, M. Internal Control Weaknesses and Accounting Conservatism: Evidence From the Post-Sarbanes-Oxley Period. J. Account. Audit. Financ. 2013, 28, 152-191. [CrossRef]

(C) 2020 by the authors. Licensee MDPI, Basel, Switzerland. This article is an open access article distributed under the terms and conditions of the Creative Commons Attribution (CC BY) license (http://creativecommons.org/licenses/by/4.0/). 